\title{
Notes on Petru Maior's language in Învățătură pentru ferirea și doftoria boalelor
}

\author{
Liliana Soare* \\ Faculty of Letters, University of Pitești, Str. Gh. Doja 41, 110253 Pitești, Romania
}

\author{
Article info \\ History: \\ Received December 4, 2015 \\ Accepted January 13, 2016 \\ Published August 1, 2016 \\ Key words: \\ literary norm \\ neologistic lexicon \\ phonetic and morphological \\ adaptation of loans
}

\begin{abstract}
Petru Maior's translation elaborated in 1816, insufficiently studied, offers precious material as regards the norms of literary language in Transylvania in the first two decades of the $19^{\text {th }}$ century. We focused on the fundamental features of the literary language, but, at the same time, we mentioned the secondary features which were considered relevant for the literary norm promoted by the scholar. It can be observed that the linguistic material extracted from this translation reflects, besides phonetic and morphologic norms specific of the author's dialect, norms established following other criteria than those exemplified by the local tradition, that is the criterion of proximity to the Latin etymon or proximity to the Wallachian rule promoted by the religious prints of the mideighteenth century. As far as the neologistic vocabulary used in this translation is concerned, a semantic classification was performed, aiming at both general cultural vocabulary, as well as at specialized vocabulary (medical terminology). The medical terminology of the text was presented on the two constituent coordinates: the literature, neologistic one and the folk, traditional one. There were considered the most important aspects of phonetic and morphological adaptation of loans, taking notice of the high number of loans properly integrated due to the Latin-Romance orientation of the scholar, as well as of the large share of analogue phonetic variants and unadapted terms (Latinisms and Italianisms).
\end{abstract}

\section{Introduction}

The second half of the eighteenth century and the first two decades of the nineteenth brought an unprecedented diversification of Romanian writing. The popularizing text that illustrated various fields of science (linguistics, geography, history, medicine, mathematics, philosophy) occupies a special place in the literature of the time. During this period, the cultural primacy is held by Transylvanian scholars who produce original, authentic scientific texts, and at the same time develop a rich activity of translation and adaptation of many texts of science popularization.

Petru Maior is the translator of several books of popularised science ${ }^{1}$ through which he contributed both to an improvement of the cultural level of his readers and to the development of literary Romanian language. Printed in Buda in 1816 with the full title Învățătură pentru ferirea şi doftoria boalelor celor ce se incing prin țeară ş si acelor ce se leağăşi a unor boale sporadice, adecăpe ici, pe colo imblätoare ale vitelor celor cu coarne, precum şi a cailor, a oilor şi a porcilor (130 pages), translated, perhaps after a Hungarian original, this text of veterinary medicine appeared in a significant period in the development of literary Romanian and raises several problems that demand to be studied. The writing contains a number of linguistic (phonetic, morphological and lexical) phenomena of importance to the history of Romanian literary language norms at the beginning of the nineteenth century. Also, being our first text of veterinary medicine, it brings a special contribution to the development of the Romanian medical language in particular and to the modernization of literary vocabulary in general.

*Email address: lilianasoare2006@yahoo.com.

${ }^{1}$ See, in this regard, Ursu (1961 and 2012). 
This study is aimed at capturing the configuration of the literary language employed by P. Maior in this translation by emphasizing phonetic, morphological and lexical peculiarities.

\section{The norms of literary language}

Regarding the literary norm promoted by P. Maior in this translation, we recorded the following phenomena:

- retention of protonic ă in: lăcuința (119), năsipos (45), păhar (54), păreții (53, 126), rădicate (8).

- retention of etymological $\hat{\imath}$ : imblare (3), imblă (20,33,36, 54, va îmbla, 23), imblătoare (f.t.), se imflă (56, imflată, 27, dar se desumflă, 78), imflături (70), a se implea (13, le implu, 18, le imple, 11, 12, 24, să se imple, 117, nu s-au implut, 55), a întra $(37,43)$ etc.

- etymological $r$ is maintained in serină(3).

- retention of etymological silent $e$ in: strein (29, streine, 31, 127), instreinarea (100).

- retention of protonic $e$ in beserică (19) and of medial $e$ in: a ceti (127, but prociti, 127), cetitoriule (127), intunerec (129).

- e preserved in detorie (115), detoriu (30,31, 50, 116).

- retention of etymological forms without the epenthetic $i$ : cînească (100), cîne (102, cînele, 102, cîni, 107, cînii, 46, etc.), mînile (36).

- unsyncopated $i$ has only one occurrence: $\operatorname{dirept}(12)$. Otherwise, there occur syncopated forms: drept $(6,18,24,128)$, dreapta (130) etc.

- retention of the prepalatal affricate in: cricima $(36$, cricime, 19), s-au obicinuit $(4,48,109,111)$.

- ia preserved: descuiarea (66), iaste (22), incuiarea (66, dar încuierei, 67), miare (47), muiarea ( pieilor, 44), pialea (60), pricinuiaște (62), pustiaște (22), tăiare (37), voiaște (129) etc., dar pietră (53).

- final ea preserved: a avea (37, vor avea, 66), ca să bea (65), prea (8, 13, 23, etc.), s-ar vedea (37) etc.

- $j$ is general: ajunge $(27,84$, nu ajung, 67, ajungă, 37, de ajuns, 38), joacă (73), judecători (29, judecătorii, 31), judele (42, judelui, 39), județ (72), jumătate (67), imprejur (35, imprejurul, 99), imprejurare (56), injugătură (35) etc.

- affricate $\breve{g}$ is preserved in the forms of the verb incunjura: se incungiură (110, să se incungiure, 89, 95, să poată încungiura, 107), încungiurate (41, ne-ncungiurată, 88), and in: gios (13), prilegiu (107, prilegiul, 40, 48, 58), prilegiuitoare (105).

- soft $r$ : crepate (77), crepătura (80, crepături, 92), intrebuințarea (122), rece (65), strimte (94), strimtorat (30, strimtorați, 23, 35), stringătoare 'astringent' (51), strinse (18), strinsuri (81), îl uresc (25) etc. alternates with hard $r$ : deoarăce (15), intrăbuințta (119), lăcrămoși (25), prăsărat (32, 114), prătul (112), putrăd (94, putrăde, 27), răce (65, răci, 64), rătrași (26), răvărsarea (82), trăbuie (21), trăbuință (118), trămura (104) etc. The palatal timbre of the vibrant $r$ is also rendered with consistency in words derived with the suffix -tor or in non-derivative words: ceriul ( gurei, 72), cuptoriul (109), curătoriu (117), muşcătoriu (110), necuvîntătoriu (3), păzitoriu (39), perzătoriul (105), vătămătoriu (6), viețitoriu (62) etc.

- hard $t$ alternates with soft $t$ : timp (31, timpul, 31), timp (102, timpul, 33, 58).

- phonetisms with hard $s, j, z, t ̦$ : asămănare (55), să se cosască (9), incățălat (61), se incățălează (92), a se însămna (109, însămnăm, 12), însătat (102), înțălepție (95), înțăles (12, înțălesul, 32), săci (92), sămnul (27), sîmțire (3), său (subst., 36), țapeni (103), țăpenirea (55), umezălei (lipsa , 78), zamă (51, zămuri, 123) etc. coexist with the soft ones: curățitoare (90), despărțit (32), se increțește (96), ințtelepțște (127), lîncezeala (81), părăsească (42), pedepsească $(29,40,49)$, să o preseri (120), să se procopsească (129), sinurile (88), slujește (111), se țin (30), umezelilor (100), se urzește (72) etc.

- soft ș: s-au aşezat (35, așezate, 25), deșeartă (adj., 124), să-i împărtăşească (24, împărtăşsesc, 118, împărtășește, 20, 100), a o înșela (48), înșelători (49), pășește (104), sfirșește (81), stropșeală (109) etc.

- hard j: să o grijască (33), grijă (8) alternates with soft j: să se grijească (38), mînjească (126), năcăjiți (107), slujește (111) etc. 
- intact labials: ferbințeală (110), a o impedeca (110, impedecă, 124, impedece, 104, 105), impedecări (18), peile (116), pelița (87), a-i peptăna (108), va peri (70), perit $(15,106$ perite, 46) etc., but also palatalised forms: fierbintătoare (113), fierbințeala (7), fiert (84), impiedece (60), împiedicată (81), piept (51), să o pierdem (21), pierzătoare (23) etc.

- use of the consonant group $g l$ instead of the palatal, out of the wish to get closer graphically to the Latin etymon: priveglearea (44), veglearea (44), but: să priveaghe (72).

- use of regional forms with a soft pronunciation of the labials: beşică (27), au beut (33), beutului (111), beutură (49, 60, 106), capet (34, capetul, 70, dar capăt, 72), ovesul (3, dar ovăs, 123), proaspet (121), se ved (55, dar se văd, 66) etc., out of the wish to reduce as much as possible the frequency of the vowels $\breve{a}$ and $\hat{\imath}$, with no correspondent in Latin..

- phonetisms with $r$ preserved: ferestrile (43), ferestri (43) coexist with those with a dissimilated $r$ : fereștile (54).

- $f$ preserved: fier $(51,115)$, fiere $(27)$ etc.

- $e>i$ in crieri (82).

- $u>o$ in: aborul (73, but aburoase, 90), notreț (38, 50), poroncească (29, 36, but poruncita, 130), răotățile (130), răotățit (61), totoș (12).

- $f>v$ in: jertvește (41), în vîrv (73, vîrvului limbei, 111).

- $s ̧>s$, by differentiation of consonant in: să se deschidă (54), deschişi (103) etc., despite the fact that the literary norm meant keeping the etymological phonetism șin deșchide (< Lat. discludere).

- $a>a ̆$ : tăbac (119).

- $l$ ' in feliu. Maior exclusively uses the palatalized form of this noun (< Hung. féle).

- The noun soartă is used in its old form, $3^{\text {rd }}$ declension: soarte (aceeaşi , 28), and gingie appears with the form imposed in literary language: gingii $(73$, gingiile, 72,73$)$.

- In Genitive-Dative, some feminine nouns belonging to the $1^{\text {st }}$ and $3^{\text {rd }}$ declension still preserve the old termination -ei: beuturei (123), cercărei (40), curățirei (126), gurei (19), inimei (123), grijei (116), ivirei (26), încuierei (67), limbei (73), mîncărei (123), primăverei (72), putrăzirei (51), rumegărei (54), trecerei (43), turbărei (117), vindecărei (60) etc.

- It is to be noticed that there is no agreement on oblique cases in constructions where the adjective is preposed to the noun it determines: asupra gangrenoasei inflamație (65), carnea trucidatei vită (80), causa sau pricina zisei boală (73), grosul întunerec al urîtei neştiință (129), pierzătoarei boală (48), proprietariul trucidatei adecă a ucisei vită (41), trucidarea sau uciderea contăgioasei vită (42), preservative sau scutitoriu asupra pierzătoarei boală (48), slăbiciune prea mare a bolnavei vită (51) etc., as well as on those in which the adjective is postposed: lățirea boalei contăgioasă (21), uciderea vitei contăgioasă (40) etc. The cases in which the agreement is made are extremely rare: răsuflarea vitei contăgioase (19).

- The variable forms of the possessive-Genitive mark are most commonly used: boalele contăgioase ale vitelor (21), imflatele picioare ale vitei (80), mortul al ei trup (32), oricarele al lor notreț (43), părți ale trupului (70), semne ale ivirei boalei de vite (26), schimbările cele fără cumpăt ale morbului (68), sinurile nărilor ale fălcei ceii din sus (88) etc. The invariable forms of the possessive-Genitive mark are underrepresented: cele mai sănătoase a vitelor bucăți (12), cumplitul a vieții rișchiu (104), stricatul aer a staurului (62), a vieței moment (125).

- The Genitive-Dative of the adjectival article is, in the feminine singular, cei(i), etymological form (< ecce + illai), and not celei, analogic form, following the plural: atingerea vitei ceii cu boală contăgioasă (19), descărcarea materiei ceii morboasă (74), dreapta osîndă a slugei ceii vicleană (130), îmflătura partei ceii pătimicioasă (78), se impută păşunei ceii umedă și băltoasă (73), materiei ceii de scabie (94), scăderea păşsunei ceii bună (61), semnele spiței dintîi adecă a ceii uşoară (101), vitei ceii dintîi contăgioasă (40) etc.

- The superlative of the adjective/adverb is built with prea, a specific feature of the old language: căldura cea prea mare a verei (8), măcar că sînt prea sănătoase (12), prea contăgioasa boală de vite (22), släbiciune prea mare a bolnavei vită (51), prea mare cruderitate (125), prea străluciților romani (127), prea bun 
părinte (129) etc. but also with foarte: pînză de in foarte subțire (16), fumegarea foarte bine se face cu oțet (54), foarte curînd (56), de foarte rău semn (57), foarte bună preservativă sau apărare (65), foarte cu de-adinsul prescriptii (53) etc.

- The use of the intensive pronouns lacking in agreement falls into the norm of the period: însăşi coarnele (19), însuşi oamenii (21), însuşi cei mai puternici moștenitori ale largilor moșii (23), însuşi de multe ori pierzătoarea boală (48) etc.

- The Genitive-Dative of the feminine demonstrative of proximity has the form aceştei in the singular: asupra aceștei pierzătoare boală (28), întru prefacerea aceștei cărticică (127), and acestor in the plural: acestor vite (66).

- Variable forms of the relative pronoun: carea (9), carele (32), carii (19) etc.

- The indefinite pronouns (adjectives) compound with fiește-: fieștecare (30), fieștecarele (31), fieștecăria ( vită, 67), fieștecine (118) etc. and ori- / oare-: oarecarele (114), oarecîtva (42), oareșce (37, 92), orice (117), oricarele (112) are frequent. Note should be made of a similar appearance for niscari ( operații, $110<$ Lat. nescio qualem), used as an adjective.

- The negative pronoun nimic appears exclusively in the form nemica (< Lat. nec mica, 26, 102, 112, 115 etc.).

- The collective numeral amindoao $(86$, amindoi, 86), met with in all literary variants and in all dialects, is doubled by $\hat{\imath} m b e(86<$ Lat. ambe), a form used only in the Banat-Hunedoara area and in certain northern dialects.

- Exclusive use of the form with etymological hiatus in the forms of the verb primi: a priimi (30), săo priimească (33), priimit (129) etc.

- Exclusive use of verbal forms with restored dental: le ard (51), pot să cadă (60), să se inchidă (38), să se radă (53), să se scoată (53), să sloboadă (50), se văd (64), să se vîndă (46) etc.

- The verbs a rămine and a ține are used in the $2^{\text {nd }}$ etymological conjugation, a form that was long preserved in the old period: de a rămînea $(31,51)$, să poată rămînea (41), vor rămînea (70), le va ținea (8), a le ținea (40), a-i ținea (108), se vor ținea (43) etc.

- The tendency to move the verbs belonging to the $3^{\text {rd }}$ Latin conjugation to -ere in the $1^{\text {st }}$ conjugation: se va adauge (68, se adauge, 102), să se adaugă (99), cură $(56,86,103)$, să poată cură (70).

- a se însănătoși is classified in the $1^{\text {st }}$ conjugation: se va însănătoşa (39), celor ce se însănătoaşă (69), with hard present.

- The $1^{\text {st }}$ conjugation verb a inconjura (ending in -(ur)a in the infinitive) has the paraxiton etymological form with $u$ in the final syllable in the present tense of the indicative and subjunctive se incungiură (110), să se încungiure $(89,95)$, săpoată încungiura (107) etc., as well as in the participle: încungiurate (41), ne-ncungiurată (88).

- Use of the ungrammatised form of the verb a ucide: să se ucidă $(32,40)$, where the grammatised forms were still frequently employed during the preparation of the text.

- a înștiința (34), which is also used with the Dative (să se inștiințeze superioritatei, 117), occurs quite frequently replaced by the verbal phrase a face (de) știre (115): să facă de știre (30), să facă știre (33, 34, 116), vor face stire (34), va face stire (39) etc.

- a mînca usually occurs in its short form, specific to Transylvanian dialects: mîncă $(25,87)$, să mînce (123), but also records an occurrence with the long, etymological form: mănîncă (66).

- a usca appears in forms with the syncope of $u$ : să se uște (53), săal uşte (126). The syncope of $u$ is also met with in the case of the verb infrumuseța: $i$-au infrumsățat (128).

- The verb (re) curăța: să se curăță (109), să se răcurățe (115, să se răcurățăă, 126) also has a form in which the affricate (assimilated to iotacised Wallachian forms) is replaced with the dental, probably out of hypercorrectness: să se curătă $(7,8)$.

- The verbs a dormita, a micşora, have hard present forms: urmă (21), se micşoară (106), dormită (103). Hard present, without a suffix, specific to the northern dialects, is also characteristic of the verb: să se lucre (121). 
- The present perfect tense has in the singular forms homonymous with the plural, etymological forms used exclusively in all literary variants of old Romanian language: această boală pierzătoare au luat inceputul său (23), prin contagiu s-au adus la oi (23), care vită s-au vindecat (24), stricătoarea boală de tot s-au așezat (35), vita carea au căzut de boală (37), iară de s-au ivit boala de vite (38), locul unde s-au ivit boala de vite (40), după ce au curs dintr-însa singele (120) etc.

- The future is usually built from the auxiliary and the infinitive verb form: se va avea grijă (89), vor avea (66), se vor incungiura (89), se va sugruma (82), va ști (61), se vor ținea (90), se va vindeca (60), vei întărîta (101), se vor întrăbuința (119), se vor vesti (91) etc., with one exception only: (gangrenei) ce va se urme (80), composed of the auxiliary and the subjunctive form of the verb.

- The analytical present conditional has structures formed of the auxiliary ar + the infinitive of the verb to be conjugated: s-ar adeveri (40), s-ar bolnăvi (34), s-ar cădea (29), s-ar doftori (96), s-ar ivi (34), s-ar pricepe (112), ar scăpa (115), ar veni (115) etc. The ones formed with the auxiliary are are not common: are fi (112); s-ar bolnăvise (40) may be a form of perfect conditional.

- Maior's preference for using the long infinitive, in constant regress during that period, is obvious ${ }^{2}$ : timpul cel rău a-l schimbare în bun (6), spre a se abate și a se scuti de fierbințeala soarelui și spre a se hodinire (7), mai vîrtos se cade a avere grijă de adăpare (8), se cade a luare aminte (9), acele animale sau vite care de aiurea mostenesc ceva întocmire spre a primire unele boale (18), înceată de a rumegare (26), inainte de a se puteare implini (41), etc. These structures coexist with those in which the short infinitive is used: incep a boli (18), sînt strimtorați a simți (22), despre primejdia răului timpuriu a-i inștiința (34), ar cuteza a păşi (39), de a curma boala (40) etc.

- The infinitive forms, better represented numerically, coexist with the concurrent subjunctive ones: vor fi detori a face de știre (50), fieștecare ar fi detoriu de orice pagubă prin cînele său cel turbat acășunată a răspunde (107), trăbuie a-i sta în coantră (35), cel ce va cuteza a face (36), să li se dea adeseori a linge sare (58), iaste op a descoperi causa (105), iaste op adecă lipsă a împuţina numărul cînilor (106), mai rar poate acest rău a se esca (106), întru acest chip spre mînie a se întărîta (107), se cade a se osărba (107), se poate mînca (80), va fi strimtorat a face (106), vor trăbui a-l păți (124), idrofobia adecă boala carea face a se îngrozi de apă (109), sub ferbințeala soarelui a se stămurare adecă a se întețire (110), cine cuteză a-l doftori (113), carele va ști lucra (118) etc.; e detoriu [...] să facă de știre (30), e detoriu să-și țină vitele (31), toate cele mai sus zise cautele adecă feriri cu de-adins trăbuie să le țină (33), trăbuie să li se poroncească (36), nu poate să vină (112), trebuie să se arunce (118) etc.

- Adverbs and adverbial phrases: adeseori (60), aliurea (42, de , 115), de aiurea (18), aliuntrea 'altminteri' (87, aliuntre, 117), altmintrea (71), amînat 'tîrziu' (73), amuş 'acum' (102), cu de-adins (9), jur-împrejur (121), din lontru (27), încătrău (30, 31), incoace și încolo (101, 103), intr-aiurea (12), într-o lături (118), lungişş si curmeziş (21, 114), oblu (19), pe ici, pe colo (25), pre alocurea (22), tomna 'tocmai' $(37,101,102)$, mai vîrtos $(44)$ etc. The semiadverb nici is used exclusively asnice $(31,52,68$, 108 etc.).

- Prepositions present old or regional phonetisms: cătră (7), dintră (39), întră (11), pănă (7), pre (24), preste (3), subt (29, supt, 6) etc. Spre is also used to express purpose ('pentru, în vederea'): spre a se abate (8), spre a se hodinire (8), spre a primire (18), spre acest scop (45), spre apărare, spre ferire, spre scutire (46) etc., and färă with adverbial meaning as well ('decît'), old meaning: nu se ved altele fără încuiarea pîntecelui (63).

- The conjunctions dar and iar appear exclusively used under the form dară, iară; sau is general, the old form au being used but extremely rare: pot după 20 de zile de la încetarea boalei au să se vîndă, au spre us, adecă întrebuințarea de casă să se întoarcă (46).

- There are several words and phonetisms specific to the writings of P. Maior that are to be found in the text investigated as well: the form atint $(38,43)$, which, sometimes, appears in correlation with

${ }^{2}$ Micu \& Șincai (1780) stated: „Poporul în convorbiri obișnuiește să omită ultima silabă $r e$ a infinitivului prezent și, în loc de a lăudare, a tăcere, a dormire etc., spun a lăuda, a tăcè etc." (51). 
cînt 'cît': atînt a stäpinnirei cînt a supuşilor (43). Atînt may be justified both by the influence of the Aromanian dialect and by that of the Italian language. However, as Ursu (1961, p. 139) observed, Maior may have restored, in an etymological spirit, the old forms atît and cit by reference to Latin (tantus, quantus) or Italian (tanto, quanto); the form esca of the verb isca: se escază (25, 94), mai rar poate acest rău a se esca (106); the loan word alsăuire 'proprietate, însuşire' (18), which he also used in other writings of his; in addition to it, there also appears the loan word enshrined in literary language: insuşire (24); the phonetism coantră for contra (a-i sta în coantră, 35, stă în coantră, 65, din coantră, 3 , $82)$; the noun $o p$ 'trebuință, necesitate' $(10,38,106)$.

- According to his conception that Romanian literary language should be enriched with loans from Aromanian $^{3}$, P. Maior also uses a few words from this dialect: se agudește (g. se intîmplă, 70), cîștiga 'grijă' (6, 30), demînda 'porunci' (29), plasă 'fel' $(6,12,59,112)$, pleaga 'rană (69), să se pleguiască (70), puştlă 'ciumă, pestă' (22).

- The influence of the Macedo-Romanian dialect may also have led to the presence of forms with prothetic $a$ : acăşunată (pagubă , 107), o acăşună (61, but căşsună, 87), acrescută (85, 86), adoita (60), amişcată (77), aroade ( pelița, 87), aroasă (pînă la os $\sim, 88$, aroase, 88$)$, se va asparge (125)

- Frequency of words derived with prefixes: se dezvînă (62), incurățirea (67), încurgere (3), necurățitele (3), necuvîntătoriu (3), neființa (3), nehodină (102), negrijă (22), prezisele (110), străsuflat (96, străsuflate, 3, 43) etc. and with suffixes: apărătoare (21), apătos (120), aprinsătură 'febră' (83), (rane) cancroase (87), pătimicioasă (78), pișcătoare (87, 92), rozitoare (92), (mîncătură) scărpinătoare (92), slobozitoare (68), tristăciune (78) etc.

- One may also note the use of words without the prefix: se va bolnăvi (32), călțămintele (36), se va cerca (54), cercărei (40), să se junghie (80), nainte (34), tuse necăcioasă (26), sănătoșare (83), se spăimîntă (103), țăpenirea (55).

- The presence of Latin terms that were out of use or only kept in dialects: arină 'nisip' (119, arinos, 45 < Lat. arena), să se astruce 'a înmormînta' ( 40 < Lat. *astruicare < astruere), cătinel 'încet, lin, domol' $\left(64,104<\right.$ Lat. ${ }^{*}$ cautelinus $)$, (semne) chiare $(117<$ Lat. clarus, $-a,-$ um $)$, curechi $(122<$ Lat. coliculus $)$, custă 'a trăi' (59 < Lat. constare: mare parte a oilor fără de vărsat custă toată viața; poate mult să custe, 87), fărina (43 < Lat. farina), junepru 'ienupăr, brădișor' (61 < Lat. juniperus), a se la 'a se spăla' (51, 54, 74 < Lat. lavo, -are), lard 'slănină (93 < Lat. lardum: puștelele curînd se incățălează și se prefac crustă adecă scoarță sau piele de lard, lardică, 93: pielea se acopere cu scoarță lardică), moare 'zeamă acră de varză' (122 < Lat. muria), morsicat 'mușcat' (124, morsicată, $118<$ Lat. morsicare).

Narrowing down our endeavour to the fundamental features of the literary norm, the main features of the language that $\mathrm{P}$. Maior uses in this translation are: maintaining of protonic $\breve{a}$ (păhar, păreții, rădicate); maintaining of etymological $\hat{\imath}$ (imfla, imbla, implea, intra); the use of etymological forms without epenthesis (cînii, mînile); ia preserved (pricinuiaște, pustiaște); final ea preserved (avea, bea); $f$ preserved (fier, fiere); exclusive $j$ exclusiv, with few exceptions (usage of the affricate in the forms of the verb incunjura: incungiura and in gios, prilegiul); soft ș (înșela, sfirş̧şste); soft $r$ in final position in non-derivative words: ceriu, сuptoriu, as well as in words derived with -tor (curătoriu, necuvintătoriu, păzitoriu, viețitoriu); soft labials (beşică, beutură, ved); variable forms of the relative pronoun and possessive-Genitive mark; the auxiliary au in the present perfect, $3^{\text {rd }}$ person singular; verbal forms with restored dental; the presence of Latin terms that were out of use or only kept in dialects, as well as the presence of words from the Aromanian dialect.

In other cases, we run across an oscillation in the use of velar or soft forms: soft and velar $r$ (rece, răce); soft and velar $t$ (timp, tîmp); soft and velar $s, j, z, t$ (părăsească, sinurile, țin, umezelilor, grijască înțăles, săci, umezălei); intact or palatalized labials (ferbințeală, împedecă, fierbințeală, împiedecă).

\footnotetext{
${ }^{3}$ In the afterword to the translation, Maior states: „,...intru prefacerea aceștei cărticică m-am întrebuințat cu mai multe dialecte ale limbei românești, din carele unele nu sînt astăzi cunoscute în patria ta...” (127).

${ }^{4}$ As noticed by Ursu (1961), some of the forms mentioned have no equivalent in the Aromanian dialect. The author may have created them by analogy with the Aromanian or Italian ones (cf. It. accréscere, aspèrgere) (p. 138).
} 
In general, P. Maior uses regional phonetisms and forms, whilst, in some cases, he remains close to the Wallachian literary norm promoted by the religious prints from the second half of the eighteenth century: $\breve{a}$ not passed in $a$, final ea kept, soft labials, $j$, mixture of soft and hard $s, j$, labial $f$ unpalatalized, phonetisms with unsyncopated $e / i$ sincopaţi etc. The scholar preserved some Wallachian phonetisms to the extent that they were able to render the form of the Latin etymons (e.g. the phonetisms with $j$ were preferred because they rendered more accurately the graphical image of the corresponding Latin words: joc < jocum, judeca < judicare; in the verb incungiura, Maior uses, for the same reason, the affricate $\breve{g}$ : < in + Lat. congyrare; even though the verbal forms with the iotacised dental were the etymological ones, Maior rejects them, preferring the innovation, the forms with the dental restored, much closer graphically to the Latin etymon).

The literary language promoted by Maior in this translation is a language that has the Wallachian literary norm of 1750-1780 as a starting point, but one that also integrates the dialects from Transylvania and Banat. Analysing literary language norms from several writings of the Transylvanian scholar, Gheție (1975, p. 484) believed that the latter should be considered the creator of Transylvanian literary norm around 1820, the first deliberate attempt to structure the Romanian literary language based on spoken and written language selections, following a unitary criterion.

\section{The semantic classification of the literate neologistic lexicon}

Regarding the neologistic lexicon, the literate terms excerpted from the text under research belong to different semantic fields; they cover, to a different extent, the spiritual and material spheres of human life. It thus becomes possible to draw a classification required by the frequency and semantic areas to which these terms belong:

\subsection{Terms relating to the human being}

- attributes, qualities: acurata (48), amoniți 'admonestați' (39), ample (65), aromatice (108, 123), complicată (82), comună (61, comuna, 31), continue (81, 84, 122), contrarii (22), corupt (94, coruptul, 62), crispă 'creață' (lînă , 92), cristalin (57), cruderă (125), denudata (99), depravate (plämînile, 82), destinatul (a., 45), diretive (21), diversă (55, diverse, 19, 21), ermii 'pustii' (107), fals (95, falsă, 95, 110), fatal (124, fatală, 81, fatalul, 34), fluid (117), fosta (78), frigidă (84, 108), funestul (105), generale (21), genuin (96), indiferent (102), liber (65), manifestă (adj., 34), mordac 'mușcător' (110), munde $(64,85)$, necesarie $(32,105,108,116$, necesarii, 107), necorupt $(108)$, nocivă $(71$, nocib, 109 , nocibe, 107), nudă $(71,93$, nude, 71, 115), nutritoare (50), ocasionale (105), parțiale (5), pendente 'care atîrnă’ (imflătură $\sim, 82$, g. adecă atîrnată, spînzurată), politicești (30), politico-veterinarii ( disposiţii, 104), prescriptul (adj., 32), profondă (63), proporționată (68, proporționate, 65), propria (42, 117), prostrată (63), prudent (95), publica (113), remot 'îndepărtat' $(32,46)$, repețita $(59,60)$, robuste (62), sapidă (95), săturat 'saturat' (84, 85), scutită (41), segregată (33), cea mai segură (112), separat (32, 40, separată, 80, separate, 31), simplă (60), spise 'gros' (73), sporadice, (f.t.), subsit (27, subsite, 36, 71), tepidă (69), trucidatei (41), vaporoasă (94), văciliți 'vacilant' (73), veget (87, vegetă, 68), (apă) vegetominerală $(69,80)$.

- actions, events, conditions, attitudes, events, feelings, objects: acrimonia (100), amînare (36), atmosfera (53), aversația (63), causă $(12,37)$, cautela 'precauție, prevedere' $(125$, cautelă, 37, 52, cautele, 33, cautelele, 13), cauție (89), celeritate (63), cerc (56), coloră (56, 81, coloara, 92, 116, coloară, 100), cruderitate (125), custodie (39), damne 'daună, pagubă (111), depunerea, (74), dialecta (128, dialecte, 127), diferență $(108,112)$, dirigență (108), distanță (34), esculente (g. bucate, 108), esempru (125, esempruri, 111, asempru, 41), faciritate (87), fenomene (83), forma (70), forța (74, cu , 39), foabă (g. groapă, 114), fosă 'groapă, accident de relief' (g. groapa, 41), gradu (86), materie (92), moment (125), moturi 'mișcări' (123), murii 'zid, perete' $(53,91)$, necesitatea (49), nutremînt $(50,108$, nutremînturi, 108), ocasia (111), oscuritate (63), penuria (61), periclu (74), periferia (37), periodul (87), personele (42), precauție (107), producturile (39, produturi, 19), public (35), răsfugarea 'emanație, evaporație' 
(83, răsfugările, 6, 25), regule (110, regulele, 21, 123), repurgația (g. curăţirea staurilor, 52), sarcină 'responsabilitate' (116), scopu (38, 67, scopul, 89, scopos, 30), scrupul 'unitate de măsură' (69), siguranță (113, siguranța, 41), speranță (83), sperare (125), speriință 'experiență' (24, 82), spese (89, speselor, 32), sterc $^{5}$ (g. balega, 108), subsire 'moarte' (50), teritoriu (112), terminul (88, 101), tirănie (125), trucidarea 'uciderea' (41), us (46), violenției (110).

- concrete actions, verbs of dicendi, movement verbs, etc.: se va acerăla (125), vor alăbora 'munci, lucra' (44), a amîna (35), amonim 'admonesta' (111), avearsă / aversă 'a urî, a avea o aversiune față de' $(101,102,104)$, să se cercete $(112$, să se cerceate, 91), a clăudica 'șchiopăta' (92), se comîndă 'a (se) recomanda' ('de veterinari se comîndă', 46), să se comită 'a se încredința' (116), să se continue $(84,122)$, decură $(63,64,93)$, a le deduce (39, să se deducă, 40), să se defalce (9), depende (74), să se descrie (116), să se dețină 'a împiedica de la ceva, a reține' (66), se devastă (23), devăgînd 'a rătăci, a umbla fără scop' (106), a devora (108), se devide (72,77), se diferesc (55), a se dimica 'a se lupta' (107, g. a se bate, a se mînca cu alți cîni), să nu se dimită 'a trimite, a lăsa să plece' (66), se împută (73), să încrustezi (80), vor îngurgita (107), să se înhume (113, 115), să se întărzică (44), să fie necesitați (108), nutri (90, nutresc, 3, se nutresc, 108, se vor nutri, 90), să obleagă 'a se îndatora, angaja' (6) ocură 'apar' (64), opoarte 'trebuie, se cuvine' (g. trăbuie, 125, 126), se oserbă (101, a se osărba, 107), să o pisezi (97), predespun (89), s-au prescris (115), preserba (113), produce (62), promove 'a mișca' (65), să se proveadă 'a înzestra cu cele necesare' (38), să-i rămoavă 'a îndepărta' (106), să se răpurge 'să se curețe' (53, 109), răsistă (65), se răsoarbe (95, se răsorb, 100), răținîndu-se (40), să se repețească (68), să nu te scăndălisești (127), spera (88, a se spera, 74), subsește (45), vor subsi (64), se termină (81), să se trucide (80, să-l trucizi, 112), văcelindu-se (103), voluta (82).

- functions, social status, professions, occupations, human relationships: coloni 'țăran ce muncește un pămînt luat în arendă de la marii proprietari' (35), comunitate (39), custode (39), econom (95, economul, 89), magistratului (72), primorilor 'cei fruntași, de rang' (29), privaților (s., 31), proprietariu $(31,90)$, servitorii (44).

- institutions, administration: $\operatorname{casa}^{6}$ (g. lada sau punga comunitatei, 41), poliţiei (36), de la superioritate (49), statul (110).

- trade: comerciul (35), confiscației (43), contraband (43).

\subsection{Terms relating to nature}

- mineral, vegetal realm; substances of mineral, vegetal origin: acid salis (50), acidi săturat (84), acidu vitrioli 'acid sulfuric' (85), sare alcală (89), arcan duplicat 'preparat de uz medicinal' (67), argilă (80), arsenic (89), auripigmentu (89), beladona (89), calam aromatic 'Acorus calamus, plantă erbacee cu utilizări în medicină $(69,89)$, calce 'oxid de calciu' (114), camfor (51), cascarila 'Croton eleuteria, arbust a cărui scoarță este folosită în medicină ca tonic și reducător al febrei’ (76, cascarilăa, 97), cenuşă clavelată 'drojdie de vin calcinat' (89), cremortartari (67), emula 'plantă' (50), furfură 'tărițte' (60), galanga 'plantă erbacee asemănătoare ghimbirului cu utilizări în medicină $(50)$, gențiana $(50,76)$, gumi de Arabia 'mucilagiu' (69), litarghiriu 'litargir, oxid de plumb topit și cristalizat' (79), minerală de Etiop (98), moshu 'mosc' (96), natura (128), savadilă 'plantă din familia liliaceelor folosită în tratamentul homeopatic al problemelor respiratorii' (pulbere de , 98), spirit vitrioli (84), tartar ametic 'tartrat de antimoniu și potasiu folosit în medicină ca vomitiv' (84), terebentină (68), valeriana (51), vanilă (97).

- animal realm: animal (adj., 61, trupul ), animal (s., 119, animalul, 103, 105, animalelor, 116), animantul (64, animantu, 112, 118, 126, animante, 24, 77, 104, 105, animantele, 104, animantului, 103), copia 'mulțime, turmă' $(6,21)$, cornută (29, cornute, 23, cornutelor, 22), domestice (36), generație 'prăsire' (95).

\footnotetext{
${ }^{5}$ Under the form șterc, the word was known in that period; the sterc phonetism may represent a reloan from Latin and Italian (Lat. stercus, It. sterco).

${ }^{6}$ Semantic loan word after cassa.
} 


\subsection{Specialised lexicon}

- medical branches, general terms, diseases: corpul (87), disenteria (27, 51), doftoria (124), doftoresc 'medical' (cuvînt , 47), s-ar doftori (96), doftoritoare (21), inferma (80), lienita 'splenită' (62), (cu) lienitidă (57), morb (81, 92, morbul, 68), morboasă (74), peripneumenia (57), prescriptul (32, prescripții, 53), scabia (94, scabiei, 94), scăbioase (93), idiopatică (77), pilule (97), remit 'a intra în remisiune' $(68,69)$, simptomatică $(77)$, simptome $(74$, simptomele 68,101$)$, urina $(63)$, veterinaria 'medicină veterinară (3);

- professions, specialists: doftor (119, doftorul, 121), hirurg $(118,119)$, personele cele doftoritoare (42), veterinariul $(49,91$, veterinari, 13$)$;

- medical institutions: lăzăret (29, 38, 39), ospital (32, 34);

- anatomy: abomas 'foios, unul dintre cele patru compartimente ale stomacului rumegătoarelor' (27), astremități (70, astremitatelor, 63), cadabru (45, 82, 87, cadabrului, 37, cădabru, 32, 71), cadăbroasă (71, cădăbros, 72), corpul (87), duoden (27), limfei (82), membrana (88), mesenteriului (ghindurile , 88), muşchi (120), nervului tendinos (111), omas 'cheag, stomacul glandular propriu-zis al rumegătoarelor' (23), stomah (69), sudorifere (90);

- physiology: apetita $(55,63,68,69$, apetită, 101), circulaţia (124), pulsu (63, 68), respirația (63), transpirația (21);

- symptomatology: diarea (26, 51), înflamația (77, înflamație, 65, înflämația, 61), înflămate (72, 73), inflämatorie (82), se întumesc 'a se inflama' (87), ostipația (66), ostruție (67), sufocativă (63), vomitu (84);

- pharmacology: antifloghistică (84, antifloghistice, 51, 84), decoct (51, 123), dosă (47, 69), emetic (s., 84), infus (52, infusu, 122, înfus, 69, înfuse, 67, înfusurile, 69), se va înstila (54), pastă (80), roborîtoare (69), stimulante (108);

- internal medicine: congestii (pl., 81), gangrenă (56,61), gangrenoasă (71, găngrenoase, 27, 82), hronice (86), se ingăngrenesc (28), metastatică (77), resoluția ( adecă desfacerea, descuiarea ostruțiilor adecă a incuierei, 67), schiroasa (86), suporința (85), supurație $(78,120,12)$;

- preventive medicine: oculația (59), preserba (112), preservativă (s., 28, 48, 57, 65, preservative, 28 , 111), preservativ (adj., 46, preservative, 21), inoculația $(59,60)$;

- curative medicine: clismă (122, clisma, 126, clismele, 84), curative (21), remediu (112, remediuri, 67);

- epidemiology: contagiu (11,94), contagios (117, contagioasa, 88, contăgios, 21), contaminate (91), a se contăgi (58), contumație 'carantină $(29,40,52)$, epidemie (77, epidimie, 54), epidemic (88, epidemică, 61,72, 81), epizootică (13, epizootice, 13), (impedecarea) propagației (105);

- surgery: amputația (111), castrația (111), cauterisația (111), cauteriu (51), circumciderea (111), foarcepă (115), operații (110), să se scarifacă $(70,120,121,126)$;

- neurology, psychiatry, psychology: deliriul (84), disposiție (66, 100, disposiții, 113, disposițiile, 38), idrofobia (109), melanhonie (101), titilație 'titilomanie' (92);

- dermatology: cicatrice (121), crustă (92), pruringine 7 (92), prurit (92, 93, 121);

- ENT, dentistry: afte (72, 73, aftele, 74), angina (15, 81, 83), palatul (72).

Along with the loans, one may encounter folk terminology. Typically, old words are used to gloss new terms: aprindere 'inflamație' (23, 57, 60), 'febră' (84), aprinsătură 'febră' (83), argint viu (99), va asuda (122), beșică 'vezică' ( cea de fiere, 27, cea de fiare, 82), beșicuțe 'afte' $(26,121)$, boală ( de gură, $\sim$ de picioare, $\sim$ de plămîni, $\sim$ de picioare sau de unghii, deplămîni 14, de splină, de ficat 15, cea mucoasă a cailor, 17), bold 'instinct' (110, g. patima), brînca 'angină' (15), călbeaza 'boală de ficat' (15), ceriul gurei 'palat' (72), ciumă (22), cufureală 'diaree' (57), curgerea mucoasă a nărilor 'rinoree' (86), deșertare 'defecație' ( a șezutului, 122), foale 'abdomen' (66, 69), foc 'febră' (84), frigurile (87), gînfarea 'inflamare' (63), se gînfă 'a se inflama' (87), ghinduri 'glandă' (88), inima rea 'dizenterie' (27), imblarea sîngelui 'cir-

${ }^{7}$ Contaminated form from prurit and pecingine (egzem, herpes)? 'Rîia iaste boală de piele cu puștele sau beșicuțe săci [...] și e rău contagios cu oareșce pruringine, adecă mîncătură scărpinătoare împreunat'. 
culație' (124), incuiere 'constipație' (67, incuiare, 63, incuietură, 102), încurgere 'influență' (3), învechita 'cronică' ( boală, 87), jalie 'jalfie, plantă aromatică (51), jugănirea (111), să se lățească 'a se propaga' (90), leacuri (36), lictariul (48), lîngoare 'febră tifoidă' (57), lupariță 'boală’ (87, g. rane cancroase), mațele (82), mațul cel gros 'intestinul gros' (27), mădulările (70), mucu 'mucozitate' (86, mucii, 86), năcreală (43), obrintitură 'inflamație' (57), pătimaşul 'pacientul, bolnavul' (122), pelin (75), peliţa 'membrana' (87), pișat (19), pişcătoare (87), rîia (17), puștea 'aftă bucală’ (71, puștlele, 55), rînză 'stomac' (26), rută 'virnanț’ (75), ruje (76), salce 'plantă erbacee cu utilizări în medicină (89), salitră (60), sarea de piatră (65), scordiu 'iarbă-usturoasă' (75), scupit 'salivă' (125), sgrăbunță 'rană' (71), sinurile 'sinus' (88), slobozirea foalelui (69), slobozire de sînge 'flebotomie' (90), slobozitoare 'diuretice' (68), spiță 'stadiu' (103), 'tip, fel' (57, 100), stîmpărată (beutură , 60), stringătoare 'astringent' (51), strinsuri 'congestie' (81), terpentin (pop. 68, de Veneția, 99, oleu de , 99), trupul (87), turbarea (17), ud 'urină' (19), umezelilor 'umoare, fire, temperament' (100), unsoare 'unguent' (75, 97, unsătura, 99), vînturi 'flatulență' (26), vintricel 'stomac' (26), viță'specie' (100) etc.

\section{Phonetic and morphological adaptation of loans}

4.1. The older forms of phonetic adaptation with $t, g^{\prime}$, and $k^{\prime}$ are almost nonexistent in the text under study: antifloghistică, litarghiriu. These are competed against by the phonetic variants in $\check{c}, \breve{g}$, which impose the Latin-Romance model of the new terms: celeritate, cerc, cicatrice, circulația, frigidă, general, generație etc.

Through the Italian influence, namely through the graphic and phonetic influence of the Italian etymon, some situations of adaptation of loans may be explained, such as the use of new words without the initial $b$ : idrofobie and the use of the following phonetisms: astremități (It. estremità), diretive (It. direttivo), melanhonie (It. malinconia), oscuritate (It. oscurità), se oserbă (It. osservare), ospital (It. ospedale), ostruție (It. ostruzione), personele (It. persona), produturi (It. prodotto), profondă (It. profondo). Through Latin one may explain such phonetisms as: comerciu (It. commercio, Lat. commercium), contagiu (It. contagio, Lat. contagio, -onis) ori necesarie (It. necessario, Lat. necessarius).

The forms with (intervocalic) $s$ reflect, in general, the graphics of the new terms of Latin-Romance provenance (Latin and Italian): cauterisație, disenterie, dosă, mesenteriului, ocasionale, preserva, spese, us etc. As far as the consonant group $c h$, is concerned, this is rendered through $h$ : hirurg, hronice.

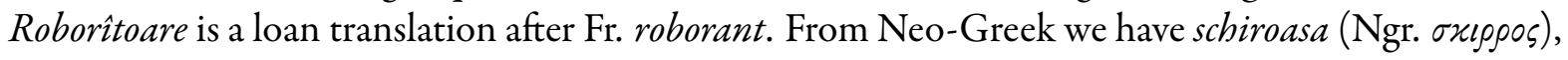
scăndălisești (Ngr. $\sigma x \alpha \nu \delta \alpha \lambda \iota \xi \omega,-\iota \sigma \alpha)$, and scopos (Ngr. $\sigma x o \pi o ́ \varsigma)$.

4.2. Analogue variants. Besides neologisms to which modern rules of phonetic adaptation apply, there are terms to which Latin phonetic laws apply, suffered by words in the old language fund.

\section{Vocalism}

- silent $a>\breve{a}$, by analogy with the old terms inherited from Latin or old loans from other languages: cădabru, cădăbros, a clăudica, a se contăgi, contăgios, devăgînd, găngrenoase, înflămate, inflămatorie, inflămație, săturat, scăbioase, să nu te scăndălisești, tirănie, văcelindu-se, văciliți.

- $a$ and $e+n+$ consonant $>\hat{\imath}$ (including in the suffix -ment): se comîndăa, nutremînt, nutreminturi.

- in-, inter-> in-, întră-/întăr-: îndiferent, înferma, înflamația, înfus, înoculația, să se întărzică8.

\section{Consonantism}

- $v>b$ : cădăbros, foabă, nocib, osărba, preserba.

- intervocalic $l>r$ : se va acerăla, cruderă, cruderitate, dirigență, esempru', faciritate.

- $r e>r a ̆$ - by analogy with the treatment of $r e$ - in inherited Latin words (răpune, răposa): să se răpurge, răsistă, se răsoarbe.

- ex- $>s-$ (under the rule according to which intervocalic $x$ became $s$, and the prefixes ex- and extrabecame $s$ - and stră-, respectively: lăsa, măsea, strămuta, străpunge): esempru, speriință.

\footnotetext{
${ }^{8}$ The phenomenon may be caused by an analogy between $i n-$ and the old prefix $i n-$.

${ }^{9}$ This may also represent a direct loan from It. esempro.
} 
As can be seen, analogue phonetismes have a relatively significant share. This is a natural consequence of the conception underlying the philological program initiated by the Transylvanian scholars, the first to establish rules for the assimilation of loans and to provide a reference model in this regard. Adaptation into Romanian of the neologisms of Latin-Romance origin is characterized in their writings by the tendency to subject them to the same phonetic changes undergone by inherited words. This process of "Romanisation" of neologisms by applying, sometimes systematically, phonetic laws highlighted by the developments of inherited elements did not prove to be sustainable (however, it was used up to 1860); instead of these forms, the further development of the literary language retained the variants that demonstrate that "Latin exercised through its phonetism and forms [...] the role of a model which influenced neologistic elements borrowed from Romance languages [...]" (Munteanu \& Țâra, 1983, p. 255), and not only from these languages, but also from Modern Greek, German or Hungarian. This is because, in the general European context, loans from Latin words that have gained the status of international words maintained their form as close as possible to the original etymon.

4.3. As far as morphological adaptation is concerned, the text under study presents an important feature (which is also the feature of the era): the special productivity of the forms with $-i e, 3^{\text {rd }}$ declension (see also Slave, 1962, p. 167). In old literary Romanian, the Latin nouns of the $3^{\text {rd }}$ declension, with the $-i o$, -ionis endings, are adapted with the -ie termination, after the Latin Nominative form. Old noun loans in -ie, feminine and masculine, of Old Slavic or Modern Greek origin, had early created a norm of noun termination adaptation, a norm that will later on be generalized in Latin Romance loans as well.

Most excerpted nouns are feminine and have been enshrined up to the present in this declension and with this termination: amputație, cauterisația, circulație, generație, inflamație, (în)oculație, operație, ostipație, precauție, propagație, resoluție, respirație, supurație, transpirație etc. Some are now considered outdated or obsolete, replaced by noun pairs, derived from long infinitives: cauterizare, inoculare, propagare, supurare. Two other words: aversație and titilație remain classified within the same declension, but were imposed in the language under slightly modified forms: aversiune and titilomanie. Culoare and vanilie are classified in the $1^{\text {st }}$ declension: coloră/coloară, vanilă.

Neologistic nouns in -(i)tate, belonging to the $3^{\text {rd }}$ declension, have Latin correspondents in -(i)tas, -(i)tatis, German correspondents in -(i)tät, Hungarian correspondents in -(i)tas, Italian correspondents in -(i)tá, French correspondents in -(i)té: celeritate, comunitate, cruderitate, faciritate, oscuritate etc.

In the texts of the period, the Latin words with the -antia, -entia endings and, by analogy, the corresponding nouns of Hungarian origin ending in -ancia, -encia,French nouns ending in -ance, -ence, German nouns ending in -anz, -enz, Italian nouns ending in -anza, -enza were adapted with the terminations -anție and -enție, $3^{\text {rd }}$ declension: audienție, corespondenție, diștanție etc. In the text written by P. Maior, such nouns appear already classified in the $1^{\text {st }}$ declension, due to the influence of Italian: diferență, dirigență, distanță, speranță.

Of the neologistic nouns with the singular form ending in -iu, of Latin-Italian origin: cauteriu, contagiu, deliriu, mesenteriu, remediu, teritoriu only the last were imposed in language with this termination. The other suffered a subsequent reloan from French, with forms without diphthongs. Contagiu was replaced with the $3^{\text {rd }}$ declension form contagiune.

Some neologistic nouns appear classified within other genres than those in which they were later established. Two situations may be observed: 1 . classification in the neuter of certain nouns to be established later on as feminine: contraband, infus/infus, periodul; 2. classification in the feminine of certain nouns to be established later on as neuter: apetita, dialecta, foarcepă, minerală, preservativă.

4.4. Regarding the class of the adjective, it is to be noted that most of the loans appear adapted under the form retained by the further development of the literary language: acurata, ample, complicată, contaminate, diversă, fluid, frigidă, genuin, segregate, veget etc.

In the period under discussion, when the number of loans from various languages increases signi- 
ficantly, the suffix -icesc served to the adaptation in Romanian, by substituting the appropriate suffixes, of many loans. In the texts of the Transylvanian scholars, whose culture was predominantly Latin and German, and who made numerous translations especially from these languages, almost all the neologistic adjectives have Latin correspondents in -icus, Italian in -ico, German in -isch, and French in -ique: analiticesc, colericesc, diplomaticesc, gramaticesc, loghicesc, metalicesc etc. In the text under study, there is only one adjective adapted with this suffix: politicesc. Otherwise, due to the Latin-Romance influence, there appear adapted forms with $-i c$, taken as such, modern forms, which were imposed later on in the language: antifloghistic, aromatice, epidemic, epizootică, idiopatică, metastatică, simptomatică.

Regarding the adaptation of neologistic adjectives coming from Latin adjectives in -alis, -arius and Italian in -ale, -ario, -are, P. Maior uses forms already adapted with the corresponding neologistic suffixes $(-a l,-a r)$, to the detriment of the suffixes specific to the period:-alicesc,-alnic,-aricesc and -arnic (see Ursu, 1969): fatal, general, parțiale.

Adjectives derived with -iv (Lat. -ivus, Fr. -if, -ive, It. -ivo, Germ. -iv) and -os (Lat. -osus, It. -oso, Fr. -eux, -euse, Germ. - $\ddot{o s}$ ) are numerous, adapted in this form from the beginning, due to the existence in Romanian of Slavic, respectively Latin derivatives with these suffixes: curativ, diretiv, nociv, preservativ, with a single exception (nutritoare 'nutritiv', derived with the old suffix -toare); cădăbros, contagios/contăgios, gangrenoasă/găngrenoase, morboasă, scăbioase, tendinos etc.

The other categories of neologistic adjectives, ending in -ant(e) / -ent(e) (adapted after adjectives of Latin origin ending in -ans, -antis, -ens, -entis, Italian in -ante, -ente, French in -ant, -ent, German in -ant, -ent), -bil (Lat. - bilis, It. - bile, Fr. -ble), are used by the Transylvannian scholar, in their most part, with the form they still have today: indiferent, pendente, prudent, stimulante. Two adjectives belonging to this class are adapted with other suffixes: roborîtoare 'roborant' and văciliți 'vacilant'.

4.5. Regarding the class of the verb, the Latin-Romance orientation of the author has enabled the entry of a large number of adapted verbs, following the Latin-Romance model, with the form retained by literary language. There appear few cases of classification in the $4^{\text {th }}$ conjugation, the most productive in that period, to the detriment of the $1^{\text {st }}$ conjugation: a se contăgi, ingăngreni (se ingăngrenesc), a (se) repeți (să se repețească), scăndălisi (să nu te scăndălisești).

Very few verbs belong de jure to the $4^{\text {th }}$ conjugation, the Latin-Romance model being observed in this case as well: Lat., It. -ere, -ire, Fr. $-i r>$ Rom. $-i$ : nutri, răsorbi.

There are times when certain verbs are used without the inflectional suffix: să se cercete/cerceate, se devastă, whilst others have a suffix: se diferesc.

4.6. As far as semantic adaptation is concerned, one may observe the use of certain lexemes with other meanings than those imposed in literary language: să se comită 'a se încredința', a devaga 'a rătăci, a umbla fără scop', a se dimite ( la păşune) 'a trimite, a lăsa să plece', generație 'prăsire', remit 'a intra în remisiune' (despre simptome).

4.7. Unadapted words. The text investigated presents a significant share of lexemes that were not imposed in the language, words that were undapated to the phonetic and morphologic system of Romanian language or words that were adapted, but which represent personal loans of the Transylvanian scholar, due to his Latin-Romance formation. From the viewpoint of their origin, they are grouped into two categories:

Latinisms: abomas (Lat. abomasum < $a b+$ omasum 'măruntaie de bou'), vor alăbora (Lat. laboro), animant (Lat. animans, -ntis), avearsă / aversă (Lat. aversor), copie (< Lat. copia), crispă (< Lat. crispus), damne (Lat. damnum), depende (Lat. dependere), a se dimica (Lat. dimico), să nu se dimită (Lat. demitto, -ere), foabă (Lat. fovea), furfură (< Lat. furfur, -uris), se intumesc (< Lat. intumesco, -ere), morbul (Lat. morbus), mordac (Lat. mordax, -cis), moturi (Lat. motus), munde (Lat. munde), murii (Lat. murus) ${ }^{10}$,

\footnotetext{
${ }^{10}$ It can also represent a loan from Aromanian (muru).
} 
ocură (Lat. occurro), omas (Lat. omasum), opoarte (Lat. oportet, -ere), periclu (Lat. periculum), primorilor (Lat. primoris), producturile (Lat. productus), promove (Lat. promoveo, -ere), să-i rămoavă (Lat. removeo, -ere), remot (Lat. remotus), salis (acid , Lat. salis), spise (Lat. spissus), subsire (Lat. subsido, -ere), tepidă (Lat. tepide), terminul (Lat. termen, -inis), trucida (Lat. trucido), trucidarea (Lat. trucidatio), văcelindu-se (Lat. vacillo), văciliți (Lat. vacillatum), voluta (Lat. voluto).

Italianisms: acidi (It. pl. acidi), amoni, amonit (It. ammonire), calam aromatic (It. calamo aromatico), cascarila (It. cascarilla), cautela (It. cautela), contumație (It. contumacia), ermii (It. pl. ermi) ${ }^{11}$, esculente (It. f. pl. esculente) ${ }^{12}$, galanga (It. galanga), să se proveadă (It. provvedere), răsfugările (It. risfogare), savadilă (It. sabadilla), veterinaria (It. veterinaria).

\section{Conclusions}

The literary language promoted by Maior in this translation has the Wallachian literary norm of the 17501780 period as starting point, reassessed in terms of Latinism and corrected with a number of phenomena specific to the dialects of Transylvania and Banat. The forms and phonetisms are chosen according to the criterion of maximum proximity to the Latin etymon, which shows that the Transylvanian scholar operated a selection in order to create a supradialectal norm.

As far as the lexicon is concerned, it is to be noted that the neologistic fund of the text is grouped around a Romance constant (Latin and Italian) which obviously contributed to the modernization of Romanian vocabulary. The high number of Latin Romance loans is relevant to the Transylvanian scholar's proximity to Western culture. The adaptation of the new words is carried out both according to the literate Latin-Romance norms and to the old, analogue ones, the criterion of maximum proximity to the Latin etymon being applied in the process of loan integration as well, not only in the selection of certain forms and phonetisms provided by the dialects. Most terms are correctly classified in the Romanian language system; they have proved their usefulness and viability and received recognition in the language under the very form used by the author. Of relevance to the Western orientation of the author (in the sense of an assumed cultural attitude and not of a subservience to the model) and to his option regarding the sources of lexical renewal are the Italianisms and Latinisms he used; some of them appear adapted to the morphological and phonetic system of Romanian, while others are ephemeral occurrences, with single confirmation.

\section{References}

Gheție, I. (1975). Baza dialectală a românei literare, Editura Academiei, București.

Micu, S. \& Șincai, Gh. (1780). Elementa lingue daco-romane sive latino-valachice, Buda; ediție critică, studiu introductiv, traducerea textelor și note de M. Zdrenghea, Cluj-Napoca, 1980.

Munteanu, Șt. \& Țâra, V. (1983). Istoria limbii române literare. Privire generală, Editura Didactică și Pedagogică, București.

Slave, E. (1962). Sufixele -ie, -ărie, în Studii și materiale privitoare la formarea cuvintelor în limba română, III, București, 1962.

Ursu, D. (1969). Adaptarea adjectivelor neologice in limba română literară din perioada 1760-1860, în „Studii de limbă literară și filologie", I, București, 1969, p. 131-154.

Ursu, N. A. (1961). Cărți de popularizare a științei traduse de Petru Maior, în „Limba română, X, nr. 2, p. 135-143.

Ursu, N. A. (2012). Alte două traduceri necunoscute ale lui Petru Maior, în „Limba română”, LXI, nr. 3, p. 413-416.

\footnotetext{
${ }^{11}$ The word can be also considered a loan from Aromanian (ermu 'pustiu').

${ }^{12}$ In Italian, the word is an adjective (< Lat. esculentus '(bun) de mîncare'). P. Maior uses it as a noun: “[...] să fie necesitați sau strimtorați de foame a devora adecă a mînca sterc (balega) strein și esculente adecă bucate putrăde”.
} 